\title{
Antidiabetic and antilipidemic effect of Ilex kaushue S.Y. Hu (Aquifoliaceae) leaves' extract on streptozotocin-induced diabetic mice
}

\author{
Nguyen Thi Huyen, Nguyen Thi Thuy, Nguyen Thi Nhung, Phan Hong Minh, Bui Thanh Tung* \\ VNU University of Medicine and Pharmacy, Vietnam National University Ha Noi, Ha Noi, Vietnam.
}

\begin{tabular}{l}
\hline ARTICLE INFO \\
\hline Received on: 08/04/2021 \\
Accepted on: 11/08/2021 \\
Available online: 03/11/2021 \\
\hline Key words: \\
Ilex kaushue S. Y. Hu, \\
streptozotocin, diabetes, \\
hypoglycemic, hypolipidemic, \\
a-glucosidase.
\end{tabular}

\begin{abstract}
Diabetes disease is a worldwide problem. Until now, there is no effective treatment. Traditional medicine uses Ilex kaushue S.Y. Hu (Aquifoliaceae) for supporting the treatment of diabetes and hyperlipidemia. This study was conducted to evaluate the $\alpha$-glucosidase inhibitory activity and the hypoglycemic and hypolipidemic effect of I. kaushue leaves' extract. Ilex kaushue leaves were extracted by ethanol 30\% with sonication 45 minutes, which was repeated thrice. Ilex kaushue leaves' extract was used to evaluate the $\alpha$-glucosidase inhibitory activity in vitro and the hypoglycemic and hypolipidemic effect in vivo on streptozotocin-induced diabetic mice $(50 \mathrm{mg} / \mathrm{kg}$ b.w. i.p.). Our results show that I. kaushue leaves' extract had a moderate $\alpha$-glucosidase inhibitory activity with an $\mathrm{IC}_{50}$ value of $147.25 \mu \mathrm{g} / \mathrm{ml}$ and strong hypoglycemic and hypolipidemic effect on diabetic mice. Our data show that I. kaushue leaves' extract has the potential antidiabetic and antilipidemic effect.
\end{abstract}

\section{INTRODUCTION}

Diabetes mellitus is characterized by frequent hyperglycemia or impaired insulin secretion for many reasons (Kerner and Bruckel, 2014). Chronic hyperglycemia often leads to a variety of disorders and complications such as organ damage, especially the heart, blood vessels, kidneys, eyes, and nerves (Reusch and Manson, 2017). Dyslipidemia is a common complication in most diabetic diseases (Mooradian, 2009). Dyslipidemia is a disorder related to hypercholesterolemia, hypertriglyceridemia, low-density lipoprotein (LDL), and decreased high-density lipoprotein (HDL). Type 2 diabetes is the most common form of diabetes, accounting for about $80 \%-90 \%$ of all diabetic patients (Williams et al., 2020). There are several different types of oral hypoglycemic agents but these drugs are expensive and have many side effects. In recent years, numerous

\footnotetext{
*Corresponding Author

Bui Thanh Tung, VNU University of Medicine and Pharmacy, Vietnam National University, Ha Noi, Ha Noi, Vietnam.

E-mail: tungbt.ump@vnu.edu.vn
}

traditional medicinal plants with antidiabetic effects have been studied. Many researchers have showed that these plants have fewer side effects (Arumugam et al., 2013).

Ilex kaushue $\mathrm{S}$. Y. Hu, also known as bitter tea, is a popular tea in many Asian countries such as Vietnam, China, and Japan. Ilex kaushue has a variety of effects according to traditional medicine, including brightening the mind and eyes, detoxifying, reducing cough and sore throat, digestive stimulation, lowering blood pressure and blood sugar, and antibacterial and anti-inflammatory properties (Li et al., 2013). Ilex kaushue leaves are also used to treat insomnia, red eyes, headache, and toothache. Phytochemical studies have showed that bitter tea leaves have many bioactive compounds such as saponins, alkaloids, triterpenoids, phenolics, and flavonoids (Li et al., 2012; Tang et al., 2005; Yi et al., 2018). Traditional medicine has used bitter tea as a beverage for reducing blood glucose in diabetes patients, but there is no scientific evidence demonstrating the antidiabetic effect of I. kaushue leaves. Therefore, this study was conducted to assess the hypoglycemic and hypolipidemic effects of I. kaushue leaves extracted by ethanol $30 \%$ on diabetic mice. 


\section{MATERIALS AND METHODS}

The leaves of I. kaushue S. Y. Hu were cultivated and harvested from Cao Bang province. Samples were identified by the Department of Pharmacognosy and Traditional Pharmacy, Medicine and Pharmacy University, Vietnam National University, Hanoi, Vietnam (UMP-VNU). A voucher specimen has been deposited in the UMP-VNU (UMP 0482020). Leaves were washed and dried at $60^{\circ} \mathrm{C}$. Eight hundred grams of dried leaves was extracted by ethanol $30 \%$ (41) with sonication for 45 minutes, which was repeated thrice. The extracts were filtered, combined, and evaporated under low pressure to obtain ethanol extract (97 g), and extraction efficiency was $12.1 \%$.

Reagents included streptozotocin (STZ) (250 mg, Aladdin, China), yeast $\alpha$-glucosidase, p-nitrophenyl- $\alpha$-Dglucopyranoside (pNPG), 4-nitrophenol (Sigma), and gliclazide (Diamicron RMR $60 \mathrm{mg}$ ). All other chemicals were of analytical grade.

The animals, Swiss albino mice, male sex, healthy, weighing $20 \pm 2 \mathrm{~g}$, were purchased from the National Institute of Hygiene and Epidemiology, Vietnam. The mice were kept in cages (10 animals per cage) under standard conditions of humidity $(50 \%$ $\pm 5 \%)$, temperature $\left(25^{\circ} \mathrm{C} \pm 2{ }^{\circ} \mathrm{C}\right)$, and light (12 hours light $/ 12$ hours dark cycle), and were fed with standard food and water ad libitum. Before the experiment was carried out, mice were adapted to their laboratory condition within 7 days.

\section{Evaluate the $\alpha$-glucosidase inhibitory activity}

The inhibitory activity of $\alpha$-glucosidase was determined according to the previously described method with some modifications (Ting et al., 2005). Appropriate dilutions of the samples $(50 \mu \mathrm{l})$ and $100 \mu \mathrm{l}$ of $\alpha$-glucosidase $(0.2 \mathrm{U} / \mathrm{ml})$ in $0.1 \mathrm{M}$ phosphate buffer $(\mathrm{pH} 6.8)$ solution were incubated at $37^{\circ} \mathrm{C}$ for 15 minutes. Then, $50 \mu 1$ of $5 \mathrm{mM}$ pNPG in $0.1 \mathrm{M}$ phosphate buffer $(\mathrm{pH}$ 6.9) solution was added. The mixtures were incubated at $37^{\circ} \mathrm{C}$ for 60 minutes. The reaction was interrupted by adding $80 \mu \mathrm{l} \mathrm{Na} \mathrm{CO}_{3} 0.2 \mathrm{M}$. The absorbance was measured at $410 \mathrm{~nm}$ in the spectrophotometer. The reference sample included all other reagents and the enzymes except the test sample. One unit of $\alpha$-glucosidase activity was defined as the amount of enzyme liberating p-nitrophenol $(1.0 \mu \mathrm{M})$ per min. The $\mathrm{IC}_{50}$ value was defined as the concentration of $\alpha$-glucosidase inhibitor that inhibited $50 \%$ of $\alpha$-glucosidase activity. Acarbose, a known $\alpha$-glucosidase inhibitor, was used as a positive control. The $\alpha$-glucosidase inhibitory activity was expressed as percentage inhibition as follows:

$$
\text { Inhibition }(\%)=\left[\left(A_{\text {ref }}-A_{\text {sample }}\right) / A_{\text {ref }}\right] \times 100
$$

\section{Evaluation of the hypoglycemic effect of I. kaushue leaves'} ethanol 30\% extract on diabetic mice induced with STZ

Method developed by Bansal et al. ’s (2012) was followed with some modifications according to our laboratory conditions. Mice were fed with a high-fat diet (containing 35\% fat in the form of lard) for 28 days to induce obesity. Mice that were over $35 \mathrm{~g}$ were used for the experiment. Then, mice had induced diabetes by injecting three doses of STZ $50 \mathrm{mg} / \mathrm{kg} / \mathrm{b}$.w. for 3 consecutive days. STZ was dissolved in $0.01 \mathrm{M}$ citrate buffer, $\mathrm{pH}$ 4.3. The physiological control group was injected with citrate buffer.

The blood samples were withdrawn from the mouse tail and blood glucose levels were measured with a portable glucose meter. After 10 days, tail bleeds were carried out and the animals with blood glucose concentrations above $10 \mathrm{mmol} / \mathrm{l}$ were considered diabetic (Flodstrom et al., 1999). The procedures for handling and care of animals adhered to the guidelines of the current international laws and policies [National Institutes of Health (NIH) Guide for the Care and Use of Laboratory Animals], and they were approved by the animal ethics committee at our university (CS.20.01/20-CN-HDDD).

The animals were randomly assigned into 5 groups of 10 mice per cage.

The control group (Group I) was given an i.p. injection of citrate buffer.

STZ-induced group (Group II) was injected with and STZ dose of $50 \mathrm{mg} / \mathrm{kg}$, i.p.

The positive control group (Group III) was injected with STZ (50 mg/kg, i.p.) + gliclazide (dose of $5 \mathrm{mg} / \mathrm{kg}$, b.w.) for 28 days.

Group IV comprised STZ-induced diabetic mice treated

with I. kaushue leaves extract (100 mg/kg, p.o.), administered orally for 28 days.

Group V comprised STZ-induced diabetic mice treated with I. kaushue leaves' extract (200 mg/kg, p.o.), administered orally for 28 days.

All groups were treated daily for 28 days, and blood glucose was monitored in $0,10,20$, and 28 days.

\section{Evaluation of the hypolipidemic effect of I. kaushue leaves' ethanol 30\% extract on diabetic mice induced with STZ}

After completing the experiment (28 days), mice were fasted for 24 hours prior to sampling. The mice were anesthetized with diethyl ether, using a $1 \mathrm{ml}$ needle to conduct a heart blood draw. After 28 days of treatment, weak samples were collected into tubes containing heparin. The serum was separated by centrifugation at $3,000 \mathrm{rpm}$ at $25^{\circ} \mathrm{C}$ for 15 minutes and sent to Hanoi Medical University Hospital for biochemical analysis: total cholesterol, HDL cholesterol, and triglycerides.

\section{Statistical analysis}

All results were expressed as $X \pm \operatorname{SEM}(X=$ average value of each group; SEM: standard error of measurement). Serial measurements were analyzed by one-way analysis of variance with Tukey's post-hoc test using Sigma Stat 3.5 program and figures were produced by using Sigma Plot 10.0 program (Systat Software Inc.). The critical significance level $\alpha$ was 0.05 and statistical significance was defined as $p<0.05$.

\section{RESULTS}

\section{a-Glucosidase inhibitory activity of I. kaushue leaves' ethanol} extract

The inhibitory effect of I. kaushue leaves' extract was determined by using pNPG as a substrate and was compared to the effect of the clinically applied $\alpha$-glucosidase inhibitor, acarbose. 
The $\alpha$-glucosidase inhibitory activity of $I$. kaushue leaves' extract is shown in Figure 1. The results showed that the I. kaushue leaves' extract had moderate $\alpha$-glucosidase inhibitory activity with an IC50 value of $147.25 \mu \mathrm{g} / \mathrm{ml}$. In this study, we compared the inhibitory $\alpha$-glucosidase effect of $I$. kaushue leaves' extract with acarbose, an $\alpha$-glucosidase inhibitor, which has been used in diabetes treatment. Acarbose inhibited $\alpha$-glucosidase activity with an IC50 value of $156.08 \mu \mathrm{g} / \mathrm{ml}$. Because the lesser the $\mathrm{IC}_{50}$, the better its inhibitory $\alpha$-glucosidase activity (Kumar et al., 2011; Thu et al., 2019; Thuy et al., 2020). Then, our results show that I. kaushue leaves' extract has a higher $\alpha$-glucosidase inhibition activity than acarbose.

\section{Hypoglycemic effect of I. kaushue leaves' extract on diabetic mice induced with STZ}

The effects of I. kaushue leaves' extract on blood glucose concentration and mouse body weights are presented in Tables 1 and 2. In Group I (control group), blood glucose levels and body weights were stable during the experiment. In Group II (diabetic group), blood glucose level and body weight had increased significantly when compared to the physiological control group. In Group III (diabetic mice treated with gliclazide), the blood glucose level and body weight significantly reduced when compared to Group II. However, when I. kaushue leaves' extract (100 and $200 \mathrm{mg} / \mathrm{kg}$, respectively) was administered, the decrease in blood glucose levels and body weight was significantly alleviated $(10.52 \pm 1.34$ and $8.91 \pm 1.12$, respectively; $p<0.05)$.

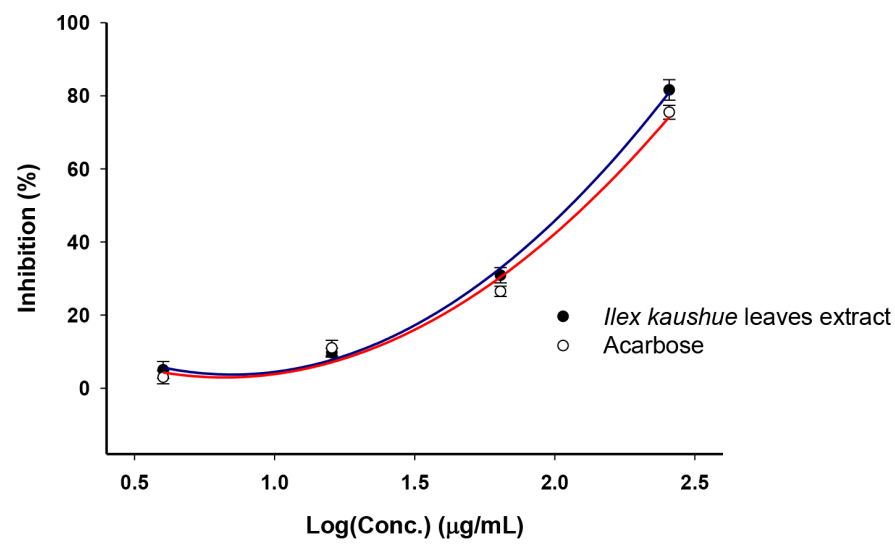

Figure 1. $\alpha$-Glucosidase inhibitory activity of I. kaushue leaves' extract.
These results indicated that I. kaushue leaves' extract has a potential antidiabetic effect to prevent and support the treatment of diabetes.

\section{Hypolipidemic effect of I. kaushue leaves' extract on mice}

Table 3 presents the effects of I. kaushue leaves' extract on blood lipid levels of mice after 28 days of treatment. Groups IV and V were treated with I. kaushue leaves' extract at a dose of 100 and $200 \mathrm{mg} / \mathrm{kg}$ which was able to reduce total cholesterol, triglyceride, and LDL cholesterol levels significantly when compared to Group II $(p<0.05)$. Furthermore, I. kaushue leaves' extract was also shown to significantly increase HDL cholesterol levels when compared to Group II $(p<0.05)$.

\section{DISCUSSION}

Type 2 diabetes is characterized by insulin resistance and impaired insulin secretion by pancreatic cells. Obesity is characterized by excess or abnormal fat accumulation in the body (Chiang et al., 2011). Fatty acid accumulation is a key factor in increasing insulin resistance. Based on this, many experimental diabetes models have been built with the tendency to create resistance and insulin and/or impair the function of beta-pancreatic cells. Each model has both advantages and disadvantages. In order to evaluate the hypoglycemic and hypolipidemic effects on obese mice with type 2 diabetes, the model of creating obese mice by high-fat diet combined with low-dose STZ of $50 \mathrm{mg} / \mathrm{kg}$ injection in mice for three consecutive days was selected.

STZ is a glucosamine nitrosourea compound, which is chemically defined as $\mathrm{C}_{8} \mathrm{H}_{15} \mathrm{~N}_{3} \mathrm{O}_{7}$. STZ has specific toxicity to insulin-producing $\beta$-cells of the pancreas in animals. STZ was found in a Streptomyces achromogenes strain in the 1950s. Currently, STZ is being used in medicine to treat some cancers of the islet of the Langerhan pancreas and also used as an effective agent to induce diabetes on experimental animal models (Lukic et al., 1998). The toxic mechanism of STZ could be explained as STZ recognizes and infiltrates $\beta$-cells via Glucose transporter 2 (GLUT2) glucose transporter, alkylates, and destroys DNA, eventually leading to cell necrosis (Kwon et al., 1994). Alkylation activity is thought to be due to the activity of the nitrosourea group, especially the $\mathrm{O}^{6}$ position of the guanine. In addition, STZ also activates ribosylation of poly(adenosine diphosphate) and the release of nitric oxide. As a result, pancreatic cells are destroyed due to necrosis (Kumar et al., 2012).

Table 1. Blood glucose level (mmol/l) in diabetic mice induced with STZ before and after 28 days of treatment using I. kaushue leaves' extract.

\begin{tabular}{|c|c|c|c|c|}
\hline Groups & Before treatment & Day 10 & Day 20 & After treatment for 28 days \\
\hline Group I: control group & $5.07 \pm 0.66$ & $5.58 \pm 1.04$ & $5.79 \pm 1.01$ & $5.14 \pm 0.91$ \\
\hline Group II: STZ + distilled water & $14.58 \pm 3.21$ & $15.02 \pm 2.24 \#$ & $16.09 \pm 2.51 \#$ & $16.23 \pm 2.31 \#$ \\
\hline Group III: STZ + gliclazide & $15.83 \pm 1.21$ & $13.25 \pm 3.32$ & $11.27 \pm 2.36^{*}$ & $9.52 \pm 2.25^{*}$ \\
\hline Group IV: STZ + IKL-100 mg/kg & $15.07 \pm 1.45$ & $13.87 \pm 1.89$ & $12.69 \pm 1.35^{*}$ & $10.52 \pm 1.34 *$ \\
\hline Group V: STZ + IKL-200 mg/kg & $14.69 \pm 2.53$ & $12.67 \pm 2.12$ & $11.57 \pm 1.82 *$ & $8.91 \pm 1.12 *$ \\
\hline
\end{tabular}

IKL: I. kaushue leaves' extract.

*Significant differences compared to Group II.

\#Significant differences compared to Group I. 
Table 2. Bodyweight (g) of diabetic mice induced with STZ before and after 28 days of treatment using I. kaushue leaves' extract.

\begin{tabular}{|c|c|c|c|c|}
\hline & Before treatment & $\begin{array}{c}\text { After treatment for } \\
15 \text { days }\end{array}$ & $\begin{array}{l}\text { After treatment for } \\
28 \text { days }\end{array}$ & $\%$ change \\
\hline Group I: control group & $35.2 \pm 0.3$ & $37.7 \pm 0.8$ & $38.2 \pm 1.7$ & Increase 8.5 \\
\hline Group II: STZ + distilled water & $36.5 \pm 2.5$ & $37.9 \pm 0.4$ & $42.2 \pm 1.1^{\#}$ & Increase 15.6 \\
\hline Group III: STZ + gliclazide & $40.3 \pm 2.8$ & $38.8 \pm 2.1$ & $34.5 \pm 3.2^{*}$ & Decrease 13.5 \\
\hline Group IV: STZ + IKL-100 mg/kg & $41.2 \pm 2.5$ & $38.4 \pm 1.2$ & $36.9 \pm 2.9^{*}$ & Decrease 11.6 \\
\hline Group V: STZ + IKL-200 mg/kg & $39.9 \pm 1.9$ & $37.3 \pm 0.7$ & $33.2 \pm 2.2^{*}$ & Decrease 16.8 \\
\hline
\end{tabular}

IKL: I. kaushue leaves' extract.

*Significant differences compared to Group II.

\#Significant differences compared to Group I.

Table 3. Hypolipidemic effect of I. kaushue leaves' extract on mice.

\begin{tabular}{ccccc}
\hline Group & Total cholesterol $(\mathbf{m g} / \mathbf{m l})$ & Triglyceride $(\mathbf{m g} / \mathbf{m l})$ & HDL cholesterol $(\mathbf{m g} / \mathbf{m l})$ & LDL cholesterol $(\mathbf{m g} / \mathbf{m l})$ \\
\hline Group I: control group & $45.78 \pm 2.5$ & $60.1 \pm 5.2$ & $42.3 \pm 3.5$ & $17.5 \pm 2.5$ \\
Group II: STZ + distilled water & $86.7 \pm 4.6^{*}$ & $97.9 \pm 5.5^{\#}$ & $16.1 \pm 3.3^{\#}$ & $50.2 \pm 2.4^{\#}$ \\
Group III: STZ + gliclazide & $65.6 \pm 5.5^{*}$ & $73.7 \pm 5.4^{*}$ & $31.9 \pm 3.4^{*}$ & $29.6 \pm 2.9^{*}$ \\
Group IV: STZ + IKL-100 mg/kg & $74.2 \pm 3.7^{*}$ & $81.4 \pm 3.1^{*}$ & $29.2 \pm 4.3^{*}$ & $43.8 \pm 4.1^{*}$ \\
Group V: STZ + IKL-200 mg/kg & $69.4 \pm 4.8^{*}$ & $76.7 \pm 5.3^{*}$ & $35.5 \pm 3.8^{*}$ & $35.4 \pm 3.5^{*}$ \\
\hline
\end{tabular}

IKL: I. kaushue leaves' extract.

*Significant differences compared to Group II.

\#Significant differences compared to Group I.

There are several levels of streptozocin that can cause diabetes. Through reference to the models of previous studies, we choose a low dose of $50 \mathrm{mg} / \mathrm{kg}$ (Akbarzadeh et al., 2007; Gajdosik et al., 1999). In this model, the high-fat diet has both obesity and insulin resistance effects, eventually increasing diabetes and increasing the risk of cardiovascular disease. Hence, low-dose STZ produces a human-like model of type 2 diabetes mouse. At the same time, low doses will also reduce complications and increase survival rates in mice. The model is based on the pathogenesis mechanism of diabetes type 2 which has the advantages of low cost, easy implementation, like human, and useful in preclinical evaluation models to treat diabetes (Lenzen, 2008; Zhang et al., 2008). Our results showed that I. kaushue leaves' extract has a moderate $\alpha$-glucosidase inhibitory activity. Moreover, the $I$. kaushue leaves' extract showed a strong hypoglycemia effect equivalent to gliclazide in diabetic mice induced by STZ.

The $\alpha$-glucosidase is an enzyme located in intestinal cell membranes, concentrated in the small intestine, involved in the absorption of sugar from the digestive system. $\alpha$-Glucosidase further decomposes disaccharides into simpler sugars, making them available for intestinal absorption. The inhibition of their activity in the digestive tracts of humans is believed to be effective in controlling diabetes because of the diminished glucose absorption. This study investigated the role of the $I$. kaushue leaves' extract in the inhibition of the activities of carbohydrate hydrolyzing enzymes and alleviation of postprandial hyperglycemia. Therefore, these enzyme preparations decrease the absorption of glucose compounds into the blood. Enzyme $\alpha$-glucosidase inhibitors have been used as drugs to regulate type 2 diabetes such as acarbose, miglitol, and voglibose (Tung et al.,
2018). Acarbose is relatively well researched and widely used in Western medicine today. Acarbose is also used as a reference for experiments $\alpha$-glucosidase inhibitory effects of other compounds (Carrascosa et al., 2001). In this study, acarbose was used as a positive control for the experimental evaluation of $\alpha$-glucosidase inhibition of I. kaushue leaves' extract. In the future, research on the isolation of compounds capable of inhibiting $\alpha$-glucosidase from I. kaushue leaves' extract is necessary.

According to traditional Vietnamese medicine, bitter tea leaves have been used to treat many ailments, including diabetes. Recent studies have also found that I. kaushue leaves' extract has many effects such as antioxidant, lipid-lowering, and state control. In in vitro research on Caco 2 cells, Wang et al. (2008) showed that glucose uptake of Caco 2 cells was inhibited by I. kaushue leaf extract (Wang et al., 2008). Song et al. (2016) reported that the total extract from I. kaushue leaves had a lipid-lowering effect on rats. The study also showed an increase in serum HDL concentrations and a significant reduction in the index of fibrosis in mice after using the extract (Song et al., 2016). Ilex kaushue leaf extract at a dose of $50 \mathrm{mg} / \mathrm{kg}$ body weight has been shown by Fan et al. (2012) to prevent body weight gain, reduce the size of fat cells, and reduce serum triglycerides, cholesterol, LDL cholesterol, fasting glucose levels, and glucose tolerance in rats with the highfat diet (Fan et al., 2012). Ethanol extraction of I. kaushue leaves was also shown to improve total cholesterol parameters, as well as Low density lipoprotein - cholesterol (LDL-C) in rats fed a high-fat diet. Studies by Linh et al. (2016) also showed that bitter tea combined with other medicinal plants' extracts is effective against diabetes and hyperlipidemia. Our results are consistent with previous studies and also show that, in mice with type 2 
diabetes after 28 days of treatment with I. kaushue leaves' extract at doses of 100 and $200 \mathrm{mg} / \mathrm{kg}$, the decrease in blood glucose level was $30.19 \%$ and $39.35 \%$, respectively, when compared with the baseline blood glucose group. At a dose of $200 \mathrm{mg} / \mathrm{kg}$, blood glucose concentrations are significantly reduced. It has also been shown to be effective in reducing triglycerides, total cholesterol, LDL cholesterol, and increasing HDL cholesterol levels.

\section{CONCLUSION}

In this study, we showed that I. kaushue leaves' extract had a moderate $\alpha$-glucosidase inhibitory activity with an $\mathrm{IC}_{50}$ value of $147.25 \mu \mathrm{g} / \mathrm{ml}$ and strong hypoglycemic and hypolipidemic effect on diabetic mice. Our results supported the effectiveness of the I. kaushue leaves' extract on the prevention and treatment of diabetes and dyslipidemia. Further studies on the isolation of the bioactive compounds from I. kaushue leaves should be conducted to clarify the effects and mechanisms of this medicinal plant.

\section{ACKNOWLEDGMENT}

This work was supported by VNU University of Medicine and Pharmacy, Vietnam National University, Hanoi, with project grant number CS.20.01.

\section{AUTHOR CONTRIBUTIONS}

All authors made substantial contributions to conception and design, acquisition of data, or analysis and interpretation of data; took part in drafting the article or revising it critically for important intellectual content; agreed to submit to the current journal; gave final approval of the version to be published; and agree to be accountable for all aspects of the work. All the authors are eligible to be an author as per the international committee of medical journal editors (ICMJE) requirements/guidelines.

\section{CONFLICT OF INTEREST}

The authors declare that they have no conflict of interests

\section{ETHICAL APPROVAL}

The study protocol was approved by the institutional animal ethics committee at our university (CS.20.01/20-CNHDDD)

\section{PUBLISHER'S NOTE}

This journal remains neutral with regard to jurisdictional claims in published institutional affiliation.

\section{REFERENCES}

Akbarzadeh A, Norouzian D, Mehrabi MR, Jamshidi S, Farhangi A, Verdi AA, Mofidian SMA, Rad BL. Induction of diabetes by Streptozotocin in rats. Indian J Clin Biochem, 2007; 22(2):60-4.

Arumugam G, Manjula P, Paari N. A review: anti diabetic medicinal plants used for diabetes mellitus. J Acute Dis, 2013; 2(3):196 200.

Bansal P, Paul P, Mudgal J, Nayak PG, Pannakal ST, Priyadarsini K, Unnikrishnan M. Antidiabetic, antihyperlipidemic and antioxidant effects of the flavonoid rich fraction of Pilea microphylla (L.) in high fat diet/streptozotocin-induced diabetes in mice. Exp Toxicol Pathol, 2012; 64(6):651-8.

Carrascosa J, Molero JC, Fermin Y, Martinez C, Andres A, Satrustegui J. Effects of chronic treatment with acarbose on glucose and lipid metabolism in obese diabetic Wistar rats. Diabetes Obes Metab, 2001; 3(4):240-8.

Chiang DJ, Pritchard MT, Nagy LE. Obesity, diabetes mellitus, and liver fibrosis. Am J Physiol Gastrointest Liver Physiol, 2011; 300(5):G697-702.

Fan S, Zhang Y, Hu N, Sun Q, Ding X, Li G, Zheng B, Gu M, Huang F, Sun YQ. Extract of Kuding tea prevents high-fat diet-induced metabolic disorders in C57BL/6 mice via liver $\mathrm{X}$ receptor (LXR) $\beta$ antagonism. PLoS One, 2012; 7(12):e51007.

Flodstrom M, Tyrberg B, Eizirik DL, Sandler S. Reduced sensitivity of inducible nitric oxide synthase-deficient mice to multiple lowdose streptozotocin-induced diabetes. Diabetes, 1999; 48(4):706-13.

Gajdosik A, Gajdosikova A, Stefek M, Navarova J, Hozova R. Streptozotocin-induced experimental diabetes in male Wistar rats. Gen Physiol Biophys, 1999; 18:54-62.

Linh HTH, Ha CTT, Thao NTT, Xuan PTT, Lieng HN, Hien LN, Hieu PQC. The lipid lipid moderating effect of product from herbal TMA (includes Gynostemma pentaphyllum, Ilex kaushue, Staphynolobium japonicum, Schyranthes bidentata, Curcuma longa) on dyslipidemia patients. J Med HCM, 2016; 20(6):65-74.

Kerner W, Bruckel J. Definition, classification and diagnosis of diabetes mellitus. Exp Clin Endocrinol Diabetes, 2014; 122(07):384-6.

Kumar S, Narwal S, Kumar V, Prakash O. $\alpha$-glucosidase inhibitors from plants: a natural approach to treat diabetes. Pharmacogn Rev, 2011; 5(9):19.

Kumar S, Singh R, Vasudeva N, Sharma S. Acute and chronic animal models for the evaluation of anti-diabetic agents. Cardiovasc Diabetol, 2012; 11(1):9.

Kwon NS, Lee SH, Choi CS, Kho T, Lee HS. Nitric oxide generation from streptozotocin 1. FASEB J, 1994; 8(8):529-33.

Lenzen S. The mechanisms of alloxan- and streptozotocininduced diabetes. Diabetologia, 2008; 51(2):216-26.

Li L, Peng Y, Ma G, He C, Feng Y, Lei Q, Xiao P. Quantitative analysis of five kudinosides in the large-leaved Kudingcha and related species from the genus Ilex by UPLC-ELSD. Phytochem Anal, 2012; 23(6):677-83

Li L, Xu LJ, Ma GZ, Dong YM, Peng Y, Xiao PG. The largeleaved Kudingcha (Ilex latifolia Thunb and Ilex kudingcha C.J. Tseng): a traditional Chinese tea with plentiful secondary metabolites and potential biological activities. J Natl Med, 2013; 67(3):425-37.

Lukic ML, Stosic-Grujicic S, Shahin A. Effector mechanisms in low-dose streptozotocin-induced diabetes. Dev Immunol, 1998; 6(12):119-28.

Mooradian AD. Dyslipidemia in type 2 diabetes mellitus. Na Rev Endocrinol, 2009; 5(3):150-9.

Reusch JE, Manson JE. Management of type 2 diabetes in 2017 getting to goal. J Am Med Assoc, 2017; 317(10):1015-6.

Song C, Yu Q, Li X, Jin S, Li S, Zhang Y, Jia S, Chen C, Xiang Y, Jiang $\mathrm{H}$. The hypolipidemic effect of total saponins from Kuding tea in highfat diet-induced hyperlipidemic mice and its composition characterized by UPLC-QTOF-MS/MS. J Food Sci, 2016; 81(5):H1313-9.

Tang L, Jiang Y, Chang HT, Zhao MB, Tu PF, Cui JR, Wang RQ. Triterpene saponins from the leaves of Ilex kudingcha. J Nat Prod, 2005; 68(8):1169-74

Ting L, Zhang X, Song Y, Liu J. A microplate-based screening method for alpha-glucosidase inhibitors. Chin J Clin Pharmacol Ther, 2005; 10(10):1128-34.

Tung BT, Thu DK, Hai PT, Hai NT. Evaluate the $\alpha$-glucosidase inhibitory effect of Punica granatum Linn extract. J Tradit Vietnamese Med Pharm, 2018; 5(18):59-63.

Thu DK, Hung VM, Trang NT, Tung BT. Study on $\alpha$-glucosidase enzyme inhibitory activity and DPPH free radical scavenging of green coffee bean extract (Coffea canephora). VNU J Sci Med Pharm Sci, 2019; $35(2): 12-18$. 
Thuy NT, Trang NHL, Binh NTT, Tung BT. Evaluation of antioxidant and $\alpha$-glucosidase inhibitory activities of Codonopsis javanica (Blume) Hook. f. Thoms' root extract. VNU J Sci Med Pharm Sci, 2020; 36(3):57-65.

Wang Z, Clifford MN, Sharp P. Analysis of chlorogenic acids in beverages prepared from Chinese health foods and investigation, in vitro, of effects on glucose absorption in cultured Caco-2 cells. Food Chem, 2008; 108(1):369-73.

Williams R, Karuranga S, Malanda B, Saeedi P, Basit A, Besancon S, Bommer C, Esteghamati A, Ogurtsova K, Zhang P, Colagiuri S. Global and regional estimates and projections of diabetes-related health expenditure: results from the International Diabetes Federation Diabetes Atlas. Diabetes Res Clin Pract, 2020; 162:108072.

Yi H, Zhou J, Shang X, Zhao Z, Peng Q, Zhu M, Zhu C, Lin C, Liu Q, Liao Q, Zhang L. Multi-component analysis of Ilex Kudingcha C. J. Tseng by a single marker quantification method and chemometric discrimination of HPLC fingerprints. Molecules, 2018; 23(4):854.
Zhang M, Lv XY, Li J, Xu ZG, Chen L. The characterization of high-fat diet and multiple low-dose streptozotocin induced type 2 diabetes rat model. Exp Diabetes Res, 2008; 2008:704045.

\section{How to cite this article:}

Huyen NT, Thuy NT, Nhung NT, Minh PH, Tung BT. Antidiabetic and antilipidemic effect of Ilex kaushue S.Y. $\mathrm{Hu}$ (Aquifoliaceae) leaves' extract on streptozotocin-induced diabetic mice. J Appl Pharm Sci, 2021; 11(11):076-081. 